\title{
Analysis on a regional basis of trends in hard coal prices for Polish households
}

ABSTRACT: The paper presents an analysis of hard coal prices offered at the coal depots in Poland. Coal depots are one of the most popular forms of purchasing coal by Polish households. Prices refer to price offers for cobble coal (grain size: 60-120 mm) and their analysis is performed based on the regions rather than on all Polish provinces. From January 2010 to May 2019, there were two regions that were distinguished in terms of price spread: the S-W region and the N-E region. In the case of the $\mathrm{S}-\mathrm{W}$ region, the difference between the province with the minimum price (Śląskie Province) and with the maximum price (Dolnośląskie Province since September 2017) ranged from PLN 53-83/ton, and in the N-E region the difference ranged PLN 64-130/ton. In the case of the remaining two regions, prices varied from a few to approximately PLN 80/ton for the N-W region, and from a few to about PLN 40 /ton for the S-E region.

In order to determine how the origin of the coal affects its prices (domestic coal, imported coal), the analysis also included cobble coal price offers that are part of the Author's own database created for several years. In the case of cobble coal from domestic producers, price offers varied betwwen PLN 14-33/GJ, and price offers for imported cobble coal stood varied between PLN 12-32/GJ. The $\mathrm{N}-\mathrm{E}$ region attracted particular attention as the price offers for imported cobble coal reached a level similar to the offers from the S-W region, i.e. the region closest to Silesian coal mines. Price diffe-

$\triangle$ Corresponding Author: Katarzyna Stala-Szlugaj, e-mail: kszlugaj@min-pan.krakow.pl

1 The Mineral and Energy Economy Research Institute, Polish Academy of Sciences, Poland; ORCID iD: 00000003-3689-7895; e-mail: kszlugaj@min-pan.krakow.pl

2019. The Author(s). This is an open-access article distributed under the terms of the Creative Commons Attribution-ShareAlike International License (CC BY-SA 4.0, http://creativecommons.org/licenses/by-sa/4.0/), which permits use, distribution, and reproduction in any medium, provided that the Article is properly cited. 
rentials within provinces belonging to a given region were influenced by the geographical rent. The paper also analyses average selling prices offered by domestic producers for various size grades of steam coal as well as selling prices for imported coal (free-at-frontier price).

KEYWORDS: hard coal, households, hard coal prices

\section{Introduction}

Hard coal is one of the most popular fuels used by Polish households. According to the latest available statistics (CSO 2017) published every three years, out of 13.4 million households in Poland in 2015, 35\% used hard coal as the primary carrier to heat their homes. Only the share of households using district heating for this purpose was 7 percentage points higher than those using hard coal.

In 2015, a statistical household in Poland (CSO 2017) consumed 2.8 tons of hard coal, and the cost of heating the useful floor area using this fuel amounted to PLN $20.75 / \mathrm{m}^{2}$. For instance, households using district heating for this purpose had to pay more by PLN $10.61 / \mathrm{m}^{2}$ in comparison to hard coal, and households using natural gas - more by PLN $4.99 / \mathrm{m}^{2}$. In total, the statistical household spent PLN 2,032 on hard coal. The comparison of prices expressed in energy units shows that the average statistical household spent PLN 28.2/GJ on hard coal, PLN 52.3/GJ on district heating and PLN 69.4/GJ on natural gas.

According to a study conducted by Sokołowski et al. (2019) in 2017, out of 13.6 million households, $10 \%$ (1.3 million households) were affected by multidimensional energy poverty. Due to the fact that hard coal is one of the cheapest energy carriers for Polish households, the aim of the paper is to analyze the prices of hard coal intended for households. The analysis included hard coal prices from 2010 to 1 H2019. Given similar price trends observed for areas larger than a province, the paper will analyze the prices on a regional basis. This breakdown was proposed by the author in a previously published article (Stala-Szlugaj 2014) and as a result Poland was divided into four regions; each region included four provinces varying in terms of industrialization, urbanization and access to domestic producers.

The adopted breakdown resulted in the following regions: the North Eastern (N-E) region: Podlaskie (POD), Warmińsko-Mazurskie (WAR), Mazowieckie (MAZ) and Łódzkie (ŁÓD) provinces, the North Western (N-W) region: Pomorskie (POM), Kujawsko-Pomorskie (KUJ), Wielkopolskie (WIE), and Zachodniopomorskie (ZAC) Provinces, the South Eastern (S-E) region: Małopolskie (MAŁ), Podkarpackie (POK), Lubelskie (LUB) and Świętokrzyskie (ŚWI) Provinces, and the South Western (S-W) region: Śląskie (ŚLĄ), Opolskie (OPO), Dolnośląskie (DOL) and Lubuskie (LBS) Provinces. 


\section{Hard coal consumption in households}

Taking all statistical groups identified among hard coal consumers in Poland in the publications of the CSO (2011-2018) into account, it can be observed that households constitute the leading group of hard coal consumers behind power stations, heat and power stations, industry and the construction sector (including coking plants).

Between 2010 and 2017, the annual consumption of hard coal varied from 8.9 to 10.8 million tons, while in the last few years it stabilized at approximately 10 million tons. At national level, the share of households accounted for $11-14 \%$ in the domestic consumption of hard coal.

The analysis of hard coal consumption in households broken down by province shows its heterogeneity (see Fig. 1). The provinces in Poland are characterized by a different density of buildings, their uneven arrangements, different age of construction, and different share of single- and multi-family residential buildings (Stala-Szlugaj 2017). These elements are among the factors affecting the consumption of hard coal in households of each province.

This uneven arrangement is well illustrated on the maps (Fig. 1) showing the consumption of hard coal in households by province. For graphical comparison, the three years taken into account are 2010, 2015 and 2017.

In these three years, the majority of provinces are classified as those with the lowest hard coal consumption, i.e. less than 0.4 million tons/year. Among these provinces are mainly those characterized by low industrialization and a relatively low number of flats. The majority are located in the northern part of Poland, and their share in the total consumption of coal by households is usually $3 \%$ each. However, among the provinces with the highest hard coal consumption (category above 1.4 million tons/year), two provinces - Śląskie and Mazowieckie - stand out (the comparison of the last two years reveals that their national share amounted to $14 \%$ ).

Calculated for 2010-2017, the coefficient of variation for hard coal consumption in households in all Polish provinces amounted to $61 \%$ (Table 1). The lowest variation in hard coal consumption was observed in households from the provinces belonging to the S-E region (Małopolskie, Lubelskie, Podkarpackie and Świętokrzyskie Provinces), and the highest in households from the S-W region (Dolnośląskie, Lubuskie, Opolskie and Śląskie Provinces) (see Fig. 1, Table 1). In the first case, the coefficient of variation was $31 \%$, and the difference between the provinces with extreme consumption of hard coal was at a similar level of about 0.5 million tons. For the provinces belonging to the S-W region, the coefficient of variation was as high as $73 \%$, and the difference between the provinces with minimum and maximum consumption ranged from 1.1 to 1.3 million tons. 



Fig. 1. Households in Poland - geographical structure of hard coal consumption by province, 2010, 2015 and 2017 Source: Author's own study based on (CSO 2011-2018)

Rys. 1. Gospodarstwa domowe w Polsce - geograficzna struktura zużycia węgla kamiennego w podziale wojewódzkim, lata 2010, 2015 i 2017

\section{Coal prices for households at national level}

Polish individual consumers, such as households, have several options to buy hard coal (Stala-Szlugaj 2017). One possibility is to purchase coal directly from a domestic producer (from a mine) or at the importers' distribution centers. However, the most popular option regardless of the origin of coal remain to buy it at a nearby coal depot. Another possibility that is gaining in popularity in the past few years is an online purchase with delivery to any place in the country as well as the purchase of coal in DIY and gardening retail chains. You can even find an offer of pre-packed coal available at petrol stations. 
TABLE 1. Households in Poland - hard coal consumption by province, 2010-2017

TABELA 1. Gospodarstwa domowe w Polsce - zmienność zużycia węgla kamiennego w podziale wojewódzkim, lata 2010-2017

\begin{tabular}{|c|c|c|c|c|c|c|}
\hline \multirow{3}{*}{ Hard coal } & \multirow{3}{*}{ Unit } & \multicolumn{5}{|c|}{ Provinces } \\
\hline & & \multirow{2}{*}{ country } & \multicolumn{4}{|c|}{ region } \\
\hline & & & $\mathrm{N}-\mathrm{W}$ & N-E & S-W & S-E \\
\hline Minimum & \multirow{5}{*}{$\begin{array}{c}\text { million } \\
\text { tons }\end{array}$} & 0.17 & 0.22 & 0.22 & 0.17 & 0.33 \\
\hline Maximum & & 1.53 & 0.93 & 1.46 & 1.53 & 0.97 \\
\hline Arithmetic average & & 0.61 & 0.52 & 0.66 & 0.66 & 0.61 \\
\hline Median & & 0.57 & 0.48 & 0.52 & 0.51 & 0.59 \\
\hline Standard deviation & & 0.37 & 0.23 & 0.45 & 0.48 & 0.19 \\
\hline Coefficient of variation & $\%$ & 61 & 44 & 68 & 73 & 31 \\
\hline
\end{tabular}

Source: author's own study based on (CSO 2011-2018).

\subsection{Selling prices offered by domestic producers of steam coal}

Statistics for households presented in the publications, among others of the CSO or the Energy Market Agency (ARE, Agencja Rynku Energii) very often relate to hard coal. In reality, however, these consumers purchase steam coal. That is why this part of the article will analyze the average selling prices of various size grades of steam coal sold by domestic producers, i.e. by the hard coal mining industry in general.

Prices presented in Figure 2 refer to steam coal sold to a group of other domestic consumers (this group includes, but is not limited to, households) and implemented by official dealers of coal companies - the so-called Authorized Coal Merchants. These prices are net prices, excluding excise duty, ex-mine, expressed both in PLN per ton (Fig. 2a) and converted into a unit of energy (PLN/GJ) (Fig. 2b).

Among size grades of steam coal purchased by households, coarse coal, medium sized coal, and coal fines prevail (collectively included in the IDA statistics, hereinafter referred to as medium sized coal).

Coarse coal recorded the highest prices which ranged from PLN 443 to 527/ton (PLN 16.4$-19.0 / \mathrm{GJ})$, in the period from 2010 to 2018 . The prices of medium sized coal were lower than those of coarse coal by about 3-10\%. The lowest prices were registered for coal fines sold at 195 to $304 \mathrm{PLN} /$ ton $(9.0-14.1 \mathrm{PLN} / \mathrm{GJ})$.

Between 2018 and 2010, the total sales of coarse coal, medium sized coal and coal fines to other domestic consumers (including households) dropped by $46 \%$ to reach 4.9 million tons (IDA 2011-2019b). The decreasing number of active coal mines contributed to the reduction of the volume of these sales. 
a) PLN/ton



b) PLN/GJ



* the price applies to steam coal fines in the ARA ports and has been adjusted to Polish conditions

Fig. 2. Average annual selling prices (net, exclusive of excise duty, ex-mine) of size grades of steam coal sold by Polish hard coal mining industry in general

(a) annual prices in PLN/ton, (b) annual prices in PLN/GJ

Source: author's own study based on (IDA 2011-2019a,b)

Rys. 2. Średnie roczne ceny (netto, bez podatku akcyzowego, loco kopalnia) sprzedaży sortymentów węgla energetycznego przez polskie górnictwo węgla kamiennego ogółem

a) roczne ceny w PLN/tonę, b) roczne ceny w PLN/GJ

During the nine years under analysis, the total sales of coarse coal and medium sized coal varied from 4.5 to 6.8 million tons, and their share in the total sales by Authorized Coal Merchants increased from $65 \%$ (in 2016) to $97 \%$ (in 2018). The increase in this share was driven by the introduction of the so-called Anti-Smog Law (Journal of Laws of 2015, item 1593). According to this act, the province parliament may, by way of a resolution, impose restrictions or prohibitions on the operation of installations as well as decide which fuel may be used.

Figure 2 also shows the average annual price of steam coal fines (CIF ARA) offered in the most important coal ports of north-western Europe, i.e. Amsterdam-Rotterdam-Antwerp (the so-called ARA ports, offer from the spot market). The price presented in the IDA publications (IDA - Industrial Development Agency; IDA 2011-2019a) has been adjusted to Polish conditions, i.e. converted into coal with Polish quality parameters.

The analysis of annual price volatility related to various size grades of steam coal and coal fines in the ARA ports shows that Polish coal prices are following the trend consistent with the international coal market. Coal prices in the aforementioned ARA ports are benchmark prices for coal imported to Europe (Lorenz and Ozga-Blaschke 2016; Grudziński 2017). In this context, however, the fact that prices in Poland have a one-year delay in relation to CIF ARA coal prices index should be taken into account. This delay is the result of agreements concluded between producers (usually for an annual period) and large coal consumers. 


\subsection{Selling prices of hard coal sold to households at the coal depots}

The graph in Figure 3 shows how hard coal prices developed for households according to ARE statistics (2011-2019). The prices are monthly prices expressed in PLN/ton and in energy units (PLN/GJ). They refer to coarse coal: rank I, cobble coal (grain size: $60-120 \mathrm{~mm}$ ) and do not include excise tax and VAT.

In the case of prices in PLN/ton, data in ARE statistics (2011-2019) are available only from May 2012. In the period from May 2012 to May 2019, prices ranged from PLN 643 to 749/ton.

Apart from the indexed coal price from the spot market, i.e. CIF ARA prices, the graph also includes the price of steam coal imported from Russia which is the main supplier of coal to the Polish market. Prices of imported Russian coal are prices at the Polish border (free-at-frontier price). It can be observed, therefore, that the changes in domestic hard coal prices had a trend similar to that on international markets (with the aforementioned one-year time delay).

In relation to the average trading price of Polish steam coal, the prices of coal for households were 2.3 to 3.1 times higher. In the case of prices expressed in PLN per unit of energy, they were higher by 1.8 to 2.7 times and in the period from January 2010 to May 2019 they ranged from PLN 23 to 29/GJ.

a) PLN/ton



b) PLN/GJ



* the price applies to steam coal fines in the ARA ports and has been adjusted to Polish conditions

** free-at-frontier price

Fig. 3. Average monthly (net) prices of hard coal for households Source: author's own study based on (ARE 2010-1H2019; IDA 2011-2019b; IDA 2014-2019)

Rys. 3. Średnie miesięczne ceny (netto) węgla kamiennego dla gospodarstw domowych 


\section{Coal prices for households on a regional basis}

In the next step, the hard coal prices on the coal depots have been analyzed on the regional level, in contrast to previously presented data for the national level.

\subsection{Selling prices of coal sold to households at the coal depots}

The graph in Figure 4 illustrates the selling prices of hard coal at the coal depots in designated regions of Poland between January 2010 and May 2019. Similarly as in Figure 3, these prices are also monthly prices and apply to cobble coal (rank I; grain size: 60-120 mm); they are expressed in PLN/ton and do not include excise duty and VAT.

The analysis of coal prices at the coal depots in individual provinces constituting part of the distinguished regions shows that the greatest price spread was observed in the provinces belonging to the S-W region (Śląskie (ŚLĄ), Opolskie (OPO), Dolnośląskie (DOL) and Lubuskie (LBS) provinces) and to the N-E region (Podlaskie (POD), Warmińsko-Mazurskie (WAR), Mazowieckie (MAZ) and Łódzkie ( $\mathrm{LO} D$ ) provinces). In the case of the $\mathrm{S}-\mathrm{W}$ region (located closest to domestic coal producers in Silesia), the difference between the minimum price (Śląskie Province) and the maximum price (Dolnośląskie Province from September 2017) ranged from PLN 83 to 153/ton. In the N-E region, the difference between the minimum price (Podlaskie Province) and the maximum price (Lódzkie Province) varied from PLN 64 to 130/ton. In the case of provinces belonging to the N-W region and the S-E region, the price spread was no longer as significant; it ranged from a few to approximately PLN 80/ton in the case of the N-W region (Kujawsko-Pomorskie (KUJ), Pomorskie (POM), Wielkopolskie (WIE) and Zachodniopomorskie (ZAC) provinces), and from a few to about PLN 40/ton in the case of the S-E region (Małopolskie (MAŁ), Lubelskie (LUB), Podkarpackie (POK) and Świętokrzyskie (ŚWI) provinces).

Price variations within provinces belonging to a given region were influenced by the geographical rent.

In almost the entire analyzed period, the lowest prices of cobble coal were observed in the Śląskie Province (the S-W region). However, in the periods from Dec 2011 to Feb 2012, Aug to Nov 2014, Apr to Sept 2015, Sept 2017, Nov 2018, and May to Sept 2018, March and May 2019, the lowest prices of cobble coal were recorded at the coal depots in the Podlaskie Province.

In addition, Figure 4 shows how the average trading price of Polish steam coal varied. Between January 2010 and May 2019, the prices of cobble coal at the coal depots in individual provinces belonging to the analyzed regions were higher than the average trading price of steam coal; in the case of the N-E region it was 2.0 to 3.3 times, in the N-W region 2.3 to 3.2 times, in the S-E region 2.3 to 3.4 times, and in the S-W region 2.0 to 3.4 times. 

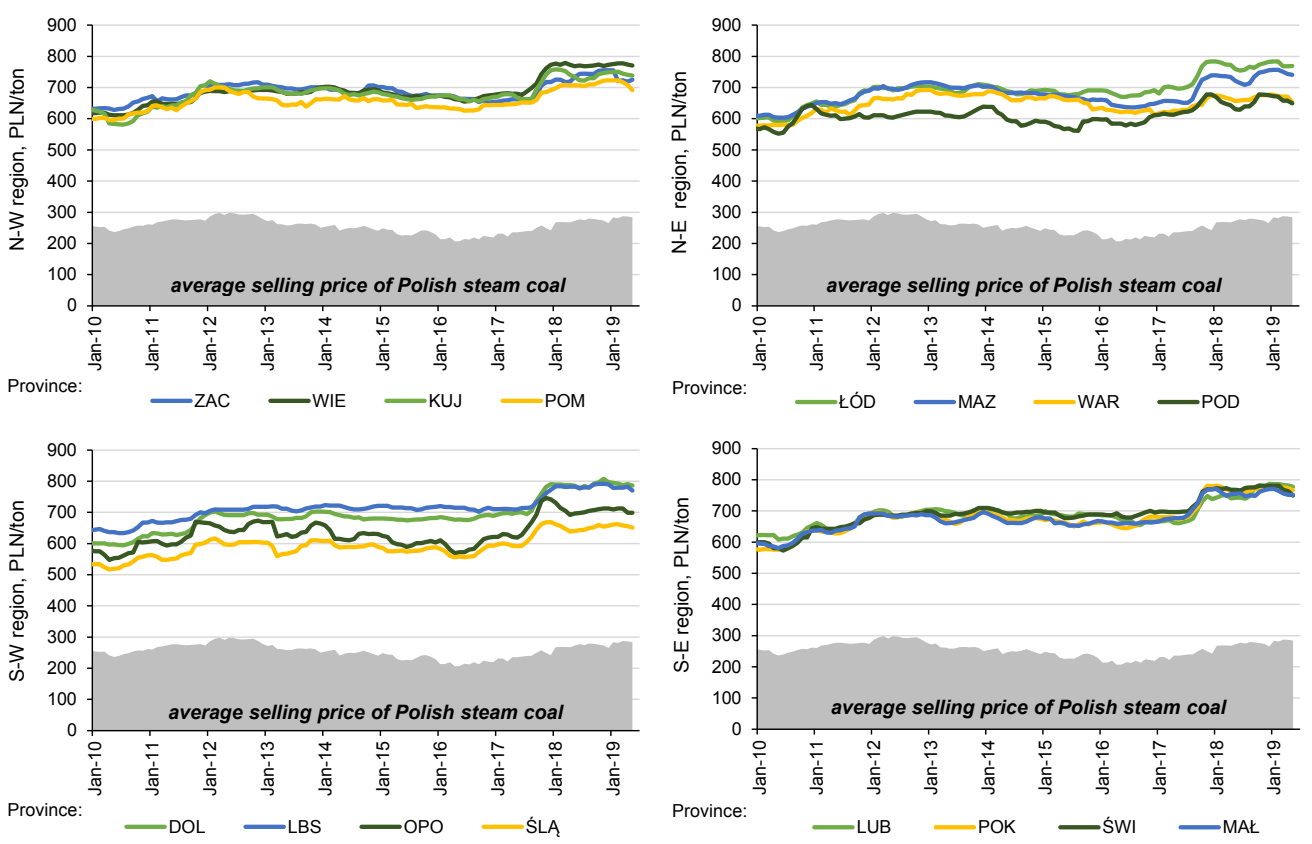

Fig. 4. Average monthly prices of hard coal at coal depots [PLN/ton] Source: author's own study based on (ARE 2010-2019)

Rys. 4. Średniomiesięczne ceny węgla kamiennego na składach opałowych [zł/tonę]

\subsection{Prices of hard coal offered at the coal depots broken down by its origin}

At the domestic coal depots, individual consumers can find both coal from domestic production and imported coal. The imports of this raw material have been a supplement to domestic coal production for many years. The fact that ARE statistics (see Figs 3 and 4) do not contain information on the coal's origin prompted the author to develop and continue her own database where these offers are differentiated for years. Price offers for coal come from the official price lists established by the coal depots.

The graphs in Figure 5 show how cobble coal price offers varied at the coal depots. These prices are net prices without excise tax. In order to enable a comparison of price offers for coal with a different calorific value, the prices expressed in PLN were converted into energy units. The prices presented in the graph refer to offers from individual quarters between 2010 and $1 \mathrm{H} 2019$.

In the case of cobble coal from domestic producers, price offers at the national level varied from PLN 14 to 33/GJ, and in the case of imported cobbles they stood at PLN 12 to 32/GJ (Fig. 4). A detailed range of cobble coal price variations broken down by the coal's origin is presented in Table 2. 
a) domestic cobble coal


b) imported cobble coal
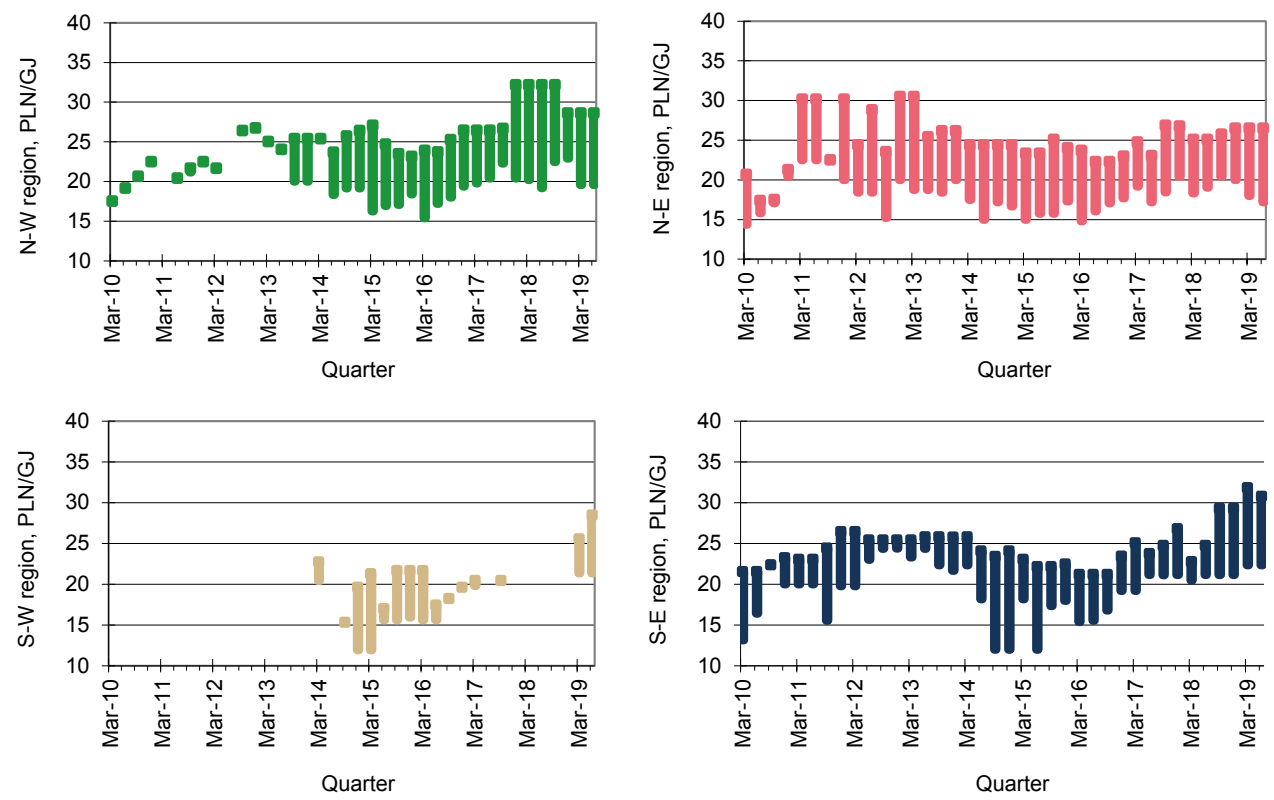

Fig. 5. Price offer (net, excluding excise tax) of (a) domestic and (b) imported cobble coal at the coal depots in Poland [PLN/GJ] (quarterly data, 2010 to 1H2019)

Source: author's own study based on data from coal depots

Rys. 5. Oferta cenowa (netto, bez podatku akcyzowego) krajowej (a) i importowanej (b) kostki na składach opałowych w Polsce [PLN/GJ] (dane kwartalne z lat 2010-1H2019) 
TABLE 2. Cobble coal prices offered at Polish coal depots broken down by coal's origin (quarterly data, 2010 to $1 \mathrm{H} 2019$ )

TABELA 2. Zakres cen kostki oferowanej w latach 2010-1H2019 (dane kwartalne) na składach opałowych w Polsce wg źródła pochodzenia węgla

\begin{tabular}{|c|c|c|}
\hline \multirow{2}{*}{ Specification } & \multicolumn{2}{|c|}{ Cobble coal price range } \\
\cline { 2 - 3 } & \multicolumn{2}{|c|}{ PLN/GJ } \\
\cline { 2 - 3 } & domestic producers & imported coal \\
\hline N-E region & $21-33$ & $14-30$ \\
\hline N-W region & $17-32$ & $15-32$ \\
\hline S-E region & $16-30$ & $12-32$ \\
\hline S-W region & $14-33$ & $12-28$ \\
\hline Total Poland & $14-33$ & $12-32$ \\
\hline
\end{tabular}

Source: author's own study.

Taking the regional breakdown into account, it can be observed that within a given quarter the range of prices for cobble coal from domestic producers was greater than the range of prices for imported cobble coal. One of the reasons causing such a spread of prices was the calorific value of this cobble coal. Its domestic offer ranged from 21 to $31 \mathrm{MJ} / \mathrm{kg}(5,000-7,400 \mathrm{kcal} / \mathrm{kg})$.

In the case of imported cobble coal - although it was in a similar range - offers prevailed with a calorific value of 23 to $24 \mathrm{MJ} / \mathrm{kg}(5,500$ to $5,700 \mathrm{kcal} / \mathrm{kg})$. This was influenced by the quality of coal from Russia, the main exporter of steam coal to the Polish market. From 2010 to 2018 (according to IDA, 2010-2019a data), 4.8 to 12.9 million tons of Russian raw material were imported accounting for $69-89 \%$ of the total imports of steam coal to Poland. The main distribution centers of Russian coal are concentrated mainly in the following provinces: Podlaskie, Warmińsko-Mazurskie, Mazowieckie and Łódzkie Provinces, which belong to the N-E region (Stala-Szlugaj 2014, 2017). Therefore, the prices of Russian coal significantly affect the spread of prices for imported coal offered at the coal depots in this region.

Figure 5 also shows that the price offers for imported cobble coal in the N-E region achieve a similar level to that of domestic cobble coal in the region closest to Silesian coal mines (the main suppliers of stove coal in Poland), i.e. the S-W region (comprising Śląskie, Opolskie, Dolnośląskie and Lubuskie Provinces).

In the case of the $\mathrm{S}-\mathrm{W}$ region, attention should also be drawn to the fact that the provinces from this region are located closest to the Czech Republic which until 2014 (inclusive) were the second most important exporter of coal to the Polish market. Thus, in the case of imported coal, the offer from this country dominated in the provinces from this region. After initial problems coming to an end with the ceasing of coal production in Czech coal mines, a slow decline can be observed in the number of imported coal offers in this part of Poland. The appearance of the $2019(1 \mathrm{H})$ prices is related mainly to Russian coal offers and an increased availability in this region results from the expansion of the distribution network of coal importers. 
Knowing how cobble coal prices vary based on its origin (domestic production or imports), it is possible to explain why the prices of coal are low at the coal depots in the Podlaskie Province (see Fig. 4). This was due to a larger share in the sales of imported cobble coal.

\section{Summary}

For Polish households, hard coal is an important fuel used for heating purposes. In addition, it is one of the cheapest energy sources. In 2015, the cost of heating the usable floor area with hard coal amounted to PLN 21/m² (CSO 2017). Compared to coal, district heating values resulted higher by PLN $11 / \mathrm{m}^{2}$, and natural gas by PLN $5 / \mathrm{m}^{2}$.

The analysis of hard coal prices (cobble coal) at the coal depots has shown that these prices vary regionally and depend on the geographical rent. The analysis of price offers for domestic cobble coal at the coal depots also revealed that prices did not vary based on their calorific value, but rather on the coal's origin (i.e. prices varied depending on producers). In almost all the analyzed years, lower price differences were observed in the case of offers for imported coal.

Among the provinces, the highest price differentials between domestic cobble coal were observed at the coal depots in the S-W region (PLN 17-32/GJ), and the lowest in the N-E region (PLN 21-33/GJ).

In the case of imported cobble coal, the offer from provinces of the N-E region is particularly noteworthy. In the aforementioned region, price offers for imported cobble coal reached a level similar to the offers from the S-W region (located closest to Silesian coal mines).

Against this background, it needs to be noted that hard coal prices gathered in national statistics (ARE 2010-2019) and which refer to hard coal sold at the coal depots refer to cobble coal only.

Taking the changing legal environment into consideration, Poland's concern for improving air quality (by introducing an increasing number of anti-smog laws), households in Poland will gradually replace the existing coal boilers with other energy carriers or with boilers intended for the combustion of other size grades (mainly qualified coal fuels such as pea coal). As a consequence, this will lead to a shift in the demand for coal size grades from household consumers.

According to Bogacz (2018), the capacity of the domestic household market is estimated at 9 million tons. According to the analyses carried out by Stala-Szlugaj (2018), as a result of changes to the existing legal conditions (especially the impact of anti-smog laws), by 2030 the demand for coal from households in Poland may decrease from 10 million tons (in 2017) to 6-7 million tons. 


\section{References}

ARE 2010-2019. European bulletin price of utility (Europejski biuletyn cenowy nośników energii). Energy Market Agency SA, Warsaw, Monthly editions from 2010-2019 (in Polish).

Bogacz, P. 2018. Proposition of Changes in the Law Governing the Combustion of Solid Fuels in Individual Energy Source used by Households in Poland in Terms of Maximizing Environmental, Social and Economic Effects. Inżynieria Mineralna, Polskie Towarzystwo Przeróbki Kopalin, Issue 1(41), pp. 195-202, DOI: 10.29227/IM-2018-01-31.

CSO 2011-2018. Consumption of Fuels and Energy carriers (Zużycie paliw i nośników energii). Central Statistical Office, Warsaw, Editions from 2011-2018 (in Polish).

CSO 2017. Energy consumption in households in 2015 (Zużycie energii w gospodarstwach domowych w 2015 r.). Central Statistical Office, Warsaw 2017, 166 pp. (in Polish).

GRUDZIŃSKI, Z. 2017. International thermal coal market (Międzynarodowy rynek wegla energetycznego). Zeszyty Naukowe Instytutu Gospodarki Surowcami Mineralnymi i Energia PAN No 98, MEERI PAS, Kraków, pp. 51-63 (in Polish).

IDA 2011-2019a. Basic information about the market and the hard coal sector in Poland (Podstawowe informacje o rynku oraz sektorze węgla kamiennego w Polsce). Industrial Development Agency JSC, data processed on the basis of the results of the statistical survey of official statistics "Mining of hard coal and lignite", maintained by the Minister of Energy and implemented by IDA JSC Branch Office in Katowice. Editions from 2010-2019 (in Polish).

IDA 2011-2019b. Selling prices and sales volumes of coal, medium sized coal and coal fines to selected groups of consumers (Ceny zbytu i wielkość sprzedaży sortymentów grubych, średnich $i$ drobnych oraz miałów do wybranych grup odbiorców krajowych). Industrial Development Agency JSC, data processed on the basis of the results of the statistical survey of official statistics "Mining of hard coal and lignite", maintained by the Minister of Energy and implemented by IDA JSC Branch Office in Katowice. Editions from 2010-2019 (in Polish).

IDA 2014-2019. Signal information on the situation on the hard coal market in Poland (Sygnalna informacja o sytuacji na rynku węgla kamiennego w Polsce). Industrial Development Agency JSC, data processed on the basis of the results of the statistical survey of official statistics "Mining of hard coal and lignite", maintained by the Minister of Energy and implemented by IDA JSC Branch Office in Katowice. Editions from 2014-2019 (in Polish).

LORENZ, U. and OZGA-BLASCHKE, U. 2016. The influence of changing market conditions on forecast prices of coal in international trade (Wpływ zmieniających się warunków rynkowych na prognozowane ceny węgla kamiennego w handlu międzynarodowym). Przegląd Górniczy No 5, pp. 3-12 (in Polish).

SoKoŁowski et al. 2019 - SokoŁowski, J., LewANDOWSKI, P., KiEŁcZEwSKA, A. and BouzArovski, S. 2019. Measuring Energy Poverty in Poland with the Multidimensional Energy Poverty Index. IBS Working Paper 07/2019. July 2019, 21 pp.

Stala-SzlugaJ, K. 2014. Price competitions in terms of regional demand for coal imports by smaller consumers (Konkurencja cenowa w aspekcie regionalnego zapotrzebowania na wegiel z importu w sektorze drobnych odbiorców). Polityka Energetyczna - Energy Policy Journal Vol. 17, Issue 4, pp. 65-76 (in Polish).

StAlA-SZlugaJ, K. 2017. Assessment of prospects for demand of coal for the municipal and household sector in Poland (Ocena perspektyw zapotrzebowania drobnych odbiorców węgla w Polsce). Studia, Rozprawy, Monografie No 203, MEERI PAS, Kraków, 216 pp. (in Polish).

Stala-SzlugaJ, K. 2018. The demand for hard coal for households in Poland and the anti-smog law. Arch. Min. Sci. 63, 3, pp. 701-711, DOI 10.24425/123692. 
The Act of 10 September 2015 amending the Act - Environmental Protection Law (in Polish). Journal of Laws of 2015 item 1593 (Ustawa z dnia 10 września 2015 r. o zmianie ustawy - Prawo ochrony środowiska. Dz.U. 2015, poz. 1593). [Online]: http://isap.sejm.gov.pl/ [Accessed: 2019-07-18] (in Polish).

\section{Analiza trendów cen węgla kamiennego dla gospodarstw domowych w Polsce w ujęciu regionalnym}

\section{Streszczenie}

Artykuł przedstawia analizę cen węgla kamiennego oferowanego na składach opałowych w Polsce. Składy opałowe węgla są jedną z najbardziej popularnym form nabywania węgla przez polskie gospodarstwa domowe. Ceny dotyczą ofert cenowych węgla kamiennego o sortymencie kostka (wielkość ziarna: 60-120 mm), przy czym analizowano je nie na poziomie wszystkich województw w kraju, lecz w podziale regionalnym. W okresie od I 2010 do V 2019 pod względem cenowym wyróżniały się dwa regiony: region $\mathrm{S}-\mathrm{W}$ oraz region N-E, które cechowały się największą rozpiętością się cen. W przypadku regionu S-W różnica między województwem o cenie minimalnej (woj. śląskie) a maksymalnej (od IX 2017 woj. dolnośląskie) zawierała się w przedziale 53-83 PLN/tonę, a regionu N-E w zakresie 64-130 PLN/tonę. W przypadku pozostałych dwóch regionów rozpiętość cen sięgała od kilku do ok. 80 PLN/tonę (dla regionu N-W) i od kilku do ok. 40 PLN/t (dla regionu S-E).

W celu określenia wpływu cen węgla ze względu na źródło jego pochodzenia (węgiel krajowy, węgiel $\mathrm{z}$ importu) przeanalizowano również oferty cenowe kostki pochodzące z własnej wieloletniej bazy autorki. W przypadku kostki pochodzącej od producentów krajowych oferty cenowe zmieniały się w zakresie od 14 do 33 PLN/GJ, a kostki importowanej w granicach od 12 do 32 PLN/GJ. Szczególną uwagę zwrócił region N-E, w którym oferty cenowe kostki pochodzącej z importu uzyskały zbliżony poziom do ofert z regionu S-W, czyli regionu położonego najbliżej śląskich kopalń węgla. Na zróżnicowanie cen w obrębie województw zaszeregowanych do danego regionu wpłynęła renta geograficzna. W artykule również poddano analizie średnie ceny sprzedaży różnych sortymentów węgla energetycznego na poziomie krajowych producentów, jak również węgla z importu (franco granica).

SŁowA KLUCZOWE: gospodarstwo domowe, węgiel kamienny, ceny węgla kamiennego 